\title{
Pencatatan Dan Penilaian Persediaan Barang Jadi Pada Usaha Gula Merah Ibu Laila Berbasiskan SAK EMKM
}

\begin{abstract}
Author: Abstrak: Penerapan akuntansi persediaan dalam pencatatan dan
Ruth Setia Hutabarat ${ }^{1}$

Thetty Surienty Rajagukguk ${ }^{2}$

Afiliation: penilaian persediaan barang jadi pada suatu perusahaan sangatlah penting karena beberapa faktor antara lain meminimalisir risiko kehilangan persediaan di gudang. Adapun penelitian ini bertujuan untuk

Politeknik Ganesha Medan

Corresponding email ruthsetiahtb@gmail.com

Histori Naskah:

Submit: 05-06-2021

Accepted: 06-06-2021

Published: 07-06-2021

mengetahui bagaimana pencatatan dan penilaian persediaan barang jadi sesuai dengan SAK EMKM 2018 menggunakan metode FIFO-Perpetual pada Usaha Gula Merah Ibu Laila yang merupakan salah satu UMKM dalam bidang produksi gula merah. Berdasarkan hasil penelitian, UMKM ini belum menerapkan sistem pencatatan dan penilaian persediaan barang jadi pada perusahaannya sesuai dengan standar akuntansi yang berlaku bagi jenis UMKM. Oleh sebab itu, disarankan agar Usaha Gula Merah Ibu Laila untuk menerapkan pencatatan dan penilaian persediaan barang jadi pada perusahaannya sesuai dengan standar akuntansi yang berlaku bagi jenis UMKM, karena dengan begitu perusahaan memiliki data yang dapat dipertanggungjawabkan apabila timbul permasalahan baik secara internal maupun eksternal pada perusahaan. Sehingga dengan dibuatnya pencatatan dan penilaian persediaan barang jadi tersebut dapat menimalisir resiko yang menimbulkan kerugian bagi pihak Usaha Gula Merah Ibu Laila.
\end{abstract}

Kata kunci: Pencatatan, Penilaian, Persediaan Barang Jadi, Metode FIFO, Sistem Perpetual, SAK EMKM 2018

\section{Pendahuluan}

Persediaan adalah bagian penting suatu perusahaan, dimana persediaan merupakan objek pendapatan utama dalam suatu usaha. Dalam hal pencatatan, jenis EMKM juga perlu untuk mencatat nilai persediaan dalam perusahaannya. Hal tersebut dikarenakan persediaan sangat rawan akan kerusakan, tidak tergantung jenis perusahaannya. Bahkan bukan hanya itu, pada berbagai kasus yang terjadi di lapangan, banyak persediaan yang hilang dari gudang penyimpanan barang atau dari lokasi kerja. Sehingga apabila tidak dilakukan pencatatan dan penilaian terhadap persediaan perusahaan, hal itu dapat memicu kejadian-kejadian yang tidak diinginkan yang dapat merugikan perusahaan.

Penilaian dan pencatatan untuk pengendalian persediaan merupakan peran yang tidak boleh diabaikan dalam proses operasional untuk mencapai tujuan perusahaan. Karena operasional perusahaan selalu berhubungan langsung terhadap persediaan. Oleh sebab itu, penulis tertarik mengambil judul tentang penerapan akuntansi persediaan.

Usaha Gula Merah Ibu Laila adalah jenis home industri yang bergerak dalam bidang produksi gula merah. Perusahaan ini mengolah sari batang pohon palem menjadi gula merah untuk didistribusikan secara offline di beberapa grosir dan pasar tradisional. Pencatatan dan penilaian persediaan barang jadi pada Usaha Gula Merah Ibu Laila dilakukan dengan cara yang sederhana. Pelaksanaannya melalui estimasi di akhir periode atau pada waktu yang khusus ditetapkan untuk menghitung keuntungan atas penjualan, tanpa mencatat terlebih dahulu jumlah produk yang di produksi dan produk yang telah dijual disetiap transaksinya. 
Permasalahan pada perusahaan ini adalah tidak optimalnya proses pencatatan dan penilaian persediaan barang jadi yang telah digunakan untuk menginterpretasikan keadaan persediaan barang jadi yang sesungguhnya. Hal itu akibat perusahaan tidak melakukan pencatatan jumlah barang jadi yang sesungguhnya diproduksi ataupun jumlah barang jadi yang sesungguhnya dijual kepada pelanggan, melainkan hanya melakukan perkiraan saja.

\section{Studi Literatur \\ Pengertian Akuntansi}

Akuntansi adalah proses yang dapat menimbulkan pertimbangan dan pengambilan keputusan bagi pengguna informasi atas data yang telah diidentifikasi, diukur, dan disampaikan dalam informasi ekonomi (Karundeng et al., 2017). Menurut (Hermanto et al., 2019), akuntansi merupakan kegiatan memproses kejadian-kejadian atau transaksi-transaksi untuk disusun sebagai laporan yang hasilnya berguna bagi pihak tertentu dan dapat mempengaruhi aktivitas bisnis.

Akuntansi juga dijabarkan sebagai kegiatan dalam bentuk jasa untuk menyajikan informasi kuantitatif suatu perusahaan (Wullur et al., 2016). Dapat disimpulkan bahwa akuntansi tidak terlepas dari suatu proses. Akuntansi juga merupakan seni pencatatan, pengidentifikasian, pengukuran, dan pelaporan informasi ekonomi dalam bentuk data kuantitatif yang dimaksudkan untuk digunakan dalam pengambilan keputusan baik oleh pihak internal maupun eksternal.

\section{Pengertian Persediaan}

SAK EMKM 2018 menjelaskan bahwa persediaan (inventory) adalah harta lancar yang diperuntukkan dijual, diproses untuk dijual, atau barang lain yang difungsikan untuk kegiatan produksi atau pemberian jasa (Ikatan Akuntan Indonesia, 2016). Setiap transaksi yang berkenaan dengan persediaan sangat erat hubungannya terhadap laba/rugi suatu perusahaan (Karongkong et al., 2018).

Umumnya, persediaan memiliki jumlah yang cukup besar di dalam perusahaan karena berperan dalam kelancaran kegiatan usaha (Budianto \& Ferriswara, 2017). Persediaan dapat diperuntukkan sebagai penjamin keberlangsungan dan kestabilan kegiatan operasional perusahaan (Budianto \& Ferriswara, 2017). Persediaan biasanya disimpan di gudang untuk dikelola maupun dijual pada waktu yang ditentukan (Lulianto et al., 2016).

\section{Jenis-Jenis Persediaan}

Jenis-jenis persediaan digolongkan berdasarkan jenis perusahaan sesuai dengan aktivitas usahanya (Karongkong et al., 2018). Pada perusahaan dagang tidak dilakukan pengolahan lanjutan terhadap persediaannya, yang disebut persediaan barang dagangan (merchandise inventory) (Barchelino, 2016). Sedangkan pada perusahaan manufaktur yang memerlukan proses pengolahan bahan baku dalam kegiatan usahanya, persediaan digolongkan menjadi persediaan bahan baku, persediaan dalam proses, dan persediaan bahan jadi (Mangopa et al., 2020).

Menurut (Mardatillah, 2020), jenis persediaan terdiri dari :

1. Persediaan barang dagang (merchandise inventory)

Persediaan barang dagang adalah barang-barang yang dibeli dari pihak lain, lalu disimpan digudang untuk dijual. Biasanya setiap barang yang akan dijual tidak lagi melalui proses pengolahan secara fisik.

2. Persediaan manufaktur (manufacturing inventory)

Persediaan manufaktur adalah jenis persediaan atas gabungan dari perusahaan manufaktur atau industri, antara lain : 
1) Persediaan bahan baku, merupakan suatu benda yang ada di perusahaan dan diperuntukkan sebagai bahan utama dalam kegiatan produksi barang yang akan dijual.

2) Persediaan barang dalam proses, merupakan suatu barang yang perlu untuk ditindaklanjuti sebelum proses produksi selesai untuk dijual. Barang dalam proses contohnya adalah alokasi biaya overhead, biaya bahan langsung, dan biaya tenaga kerja langsung yang timbul hingga tanggal tertentu.

3) Persediaan barang jadi, merupakan hasil dari proses produksi perusahaan yang berbentuk barang untuk dijual.

4) Persediaan perlengkapan manufaktur, adalah barang lain yang mendukung proses produksi. Umumnya memiliki peran yang tidak rutin dan jarang dibutuhkan untuk memproduksi barang yang akan dijual.

3. Persediaan rupa-rupa

Persediaan rupa-rupa adalah barang-barang yang rutin digunakan sebuah perusahaan dan memiliki harga yang cenderung murah. Pencatatan persediaan rupa-rupa menggunakan akun yang termasuk bahan penjualan atau umum.

\section{Sistem Pencatatan Persediaan}

Terdapat 2 jenis sistem pencatatan persediaan menurut (Lestari et al., 2019), yaitu sistem pencatatan periodik dan sistem pencatatan perpetual. Pada sistem periodik, apabila terjadi pembelian, maka pencatatan jurnalnya menggunakan akun pembelian didebet dan kas atau utang dagang dikredit. Sedangkan untuk transaksi penjualan, pencatatan jurnalnya menggunakan akun kas atau piutang dagang didebet dan penjualan dikredit.

Pada sistem pencatatan perpetual setiap transaksi pembelian dicatat menggunakan akun persediaan barang dagang didebet, akun kas atau utang dagang dikredit. Pada sistem pencatatan ini, terdapat dua jurnal untuk mencatat transaksi penjualan. Akun dalam mencatat jurnal pertama penjualan menggunakan metode ini sama dengan sistem periodik. Sedangakan akun dalam jurnal kedua, harga pokok produksi dicatat pada debet dan persediaan barang dagang pada kredit (Lestari et al., 2019).

Pada sistem periodik, pencatatan persediaan dilakukan secara berkala. Sedangkan pada sistem perpetual, pencatatan persediaan dilakukan setiap saat transaksi yang berkenaan dengan persediaan, seperti pada saat terjadi transaksi barang masuk atau keluar (Yosefa, 2016).

Berdasarkan SAK EMKM 2018, persediaan dicatat pada kelompok aset (Ikatan Akuntan Indonesia, 2016). Jika terjadi penjualan atas persediaan, maka totalnya masuk ke dalam akun beban pada periode tanggal berjalan (Ikatan Akuntan Indonesia, 2016).

\section{Metode Penilaian Persediaan}

Menurut (Yosefa, 2016) terdapat 3 metode untuk menilai persediaan, antara lain :

1. Masuk Pertama Keluar Pertama (FIFO)

Metode ini dimaksudkan, setiap persediaan yang selesai diproduksi pertama kali atau dibeli pertama kali menjadi yang diutamakan untuk dijual. Hal tersebut membuat persediaan barang akhir periode adalah persediaan yang terakhir kali diproduksi.

2. Masuk Terakhir Keluar Pertama (LIFO)

Pada metode ini setiap persediaan yang selesai diproduksi terakhir kali atau dibeli terakhir kali menjadi yang diutamakan untuk dijual. Hal itu menjadikan persediaan yang diproduksi pertama kali akan menjadi persediaan diakhir periode.

3. Moving Average 
Metode Moving Average atau rata-rata bergerak adalah salah satu metode yang digunakan untuk menilai persediaan untuk dijual ataupun sisa berdasarkan nilai rata-rata bergeraknya.

Metode penilaian persediaan yang biasa dipakai yaitu metode identifikasi khusus, biaya rata-rata, masuk pertama keluar pertama, dan masuk terakhir keluar pertama (Hutauruk, 2019). Sedangkan sejak tahun 2008 metode penilaian persediaan yang berlaku untuk digunakan hanyalah metode rata-rata dan metode masuk pertama keluar pertama (MPKP) (Hutauruk, 2019).

Penjelasan mengenai metode penilaian persediaan masuk pertama keluar pertama dan metode rata-rata dalam (Hutauruk, 2019) adalah sebagai berikut :

1. Metode masuk pertama keluar pertama (MPKP)

Dalam penerapannya, metode ini sering menggunakan istilah first in first out. Metode MPKP merupakan metode penilaian terhadap persediaan dengan mengeluarkan setiap barang yang terlebih dahulu diperoleh. Oleh sebab itu, metode ini menjadikan nilai persediaan akhir perusahaan merupakan harga pokok persediaan yang paling akhir. Yang dinilai dalam metode akuntansi persediaan adalah nilai perolehan atau harga pokok persediaan barang, bukan persediaan berbentuk fisik.

2. Metode rata-rata

Metode rata-rata terbagi menjadi 2, yaitu :

1) Metode rata-rata tertimbang (weighted average), dalam penilaian persediaan metode ini memakai sistem periodik. Cara menilai persediaan dalam perusahaan apabila menggunakan metode weighted average adalah dengan mencari rata-rata atas persediaan yang siap dijual berdasarkan harga perolehan persediaan akhir dan harga pokok penjualannya.

2) Metode rata-rata bergerak (moving average), dalam penilaian persediaan metode ini memakai sistem perpetual. Cara menilai persediaan dalam perusahaan adalah dengan mencari rata-rata dari setiap barang masuk yang baru untuk harga pokok perolehan dan rata-rata setiap perkalian seluruh persediaan yang akan keluar untuk harga pokok penjualan.

\section{Kartu Persediaan}

Kartu persediaan adalah kolom-kolom yang difungsikan untuk menuliskan perubahan persediaan dalam suatu perusahaan (Khadijah, 2019). Kartu persediaan berguna dalam pencatatan perhitungan fisik persediaan perusahaan (Agus, 2019).

\section{Metode Penelitian}

\section{Jenis Data}

1. Data Kulitatif

Data kualitatif adalah data yang berebentuk keterangan yang dinyatakan dalam bentuk selain angka. Contoh data kualitatif adalah, baik, buruk, meningkat, menurun, dan lain-lain.

2. Data Kuantitatif

Data kuantitatif adalah jenis data yang dinyatakan dalam bentuk angka seperti, nilai rupiah, suku bunga, jumlah, dan lainnya.

\section{Sumber Data}

1. Data Primer (Primary Data)

Data primer adalah data yang diperoleh dengan penelitian secara langsung kepada pihak terkait sesuai informasi yang ingin ditemukan, dapat berupa observasi dan atau wawancara.

2. Data Sekunder (Secondary Data) 
Data sekunder adalah data yang diperoleh dengan menyatukan informasi dari berbagai studi atau penelitian sebelumnya yang telah diterbitkan secara sah oleh pihak yang berwenang dalam bidangnya. Data sekunder contohnya adalah data dokumentasi dan atau arsip-arsip resmi.

\section{Metode Pengumpulan Data}

Metode pengumpulan data dilakukan dengan cara :

1. Studi Lapangan (Field Research), yaitu metode penelitian dengan meninjau langsung dalam hal mengamati dan meneliti perusahaan yang terkait (observasi) dan melakukan tanya jawab atau wawancara langsung kepada pihak-pihak yang bersangkutan.

2. Studi Pustaka (Library Research), yaitu metode penelitian dengan melakukan studi literatur dengan membaca berbagai referensi, bahan kuliah, dan hasil penelitian sebelumnya sebagai bahan pertimbangan.

\section{Metode Analisis Data}

Metode penelitian yang digunakan adalah deskriptif kualitatif. Metode kualitatif deskriptif adalah jenis metode dalam penelitian yang bertujuan untuk mengungkapkan fakta kejadian, keadaan, fenomena variabel, dan keadaan yang sebenarnya terjadi saat penelitian berlangsung. Kegiatan dalam metode penelitian deskriptif kualitatif meliputi pengumpulan data, menganalisis data, menginterpretasikan data, dan diakhiri dengan kesimpulan.

\section{Hasil}

Berdasarkan penelitianUsaha Gula Merah Ibu Laila tidak melakukan pencatatan ataupun penilaian secara terus menerus khususnya pada jenis persediaan barang jadi. Sehingga pihak yang membutuhkan informasi tersebut tidak dapat langsung mengetahui nilai persediaan barang jadi perusahaan.

Apabila pemilik usaha ingin mengetahui nilai persediaan barang jadi perusahaan, pihak yang bersangkutan harus melakukan perhitungan fisik barang jadi yang tersedia di gudang. Dalam perhitungannya, usaha ini tidak menyertakan pencatatan persediaan barang jadi sesuai dengan strandar, melainkan hanya menggunakan pencatatan sederhana seperti coretan dalam selembar kertas. Oleh karena itu, tingkat resiko kecurangan menjadi sangat tinggi.

Berikut ini data periode triwulan IV (1 Oktober-31 Desember 2020) pada Usaha Gula Merah Ibu Laila adalah sebagai berikut :

Tabel 1. Persediaan Awal Barang Jadi Per 01 Oktober 2020

\begin{tabular}{|c|c|c|c|r|r|}
\hline No. & Nama Barang & Unit & Satuan & Harga/Unit & \multicolumn{1}{c|}{ Jumlah } \\
\hline 1. & Gula Merah Kecil & 20 & $\mathrm{Kg}$ & $\mathrm{Rp} 17.000$ & $\mathrm{Rp} 340.000$ \\
\hline 2. & Gula Merah Besar & 20 & $\mathrm{Kg}$ & $\mathrm{Rp} 17.000$ & $\mathrm{Rp} 340.000$ \\
\hline \multicolumn{2}{|c|}{ Jumlah } & $\mathbf{4 0}$ & & & Rp680.000 \\
\hline
\end{tabular}

Sumber : Diolah Penulis

Tabel 2. Daftar Produksi Barang Jadi Periode Oktober 2020

\begin{tabular}{|c|c|c|c|r|r|}
\hline No. & Nama Barang & Unit & Satuan & Harga/Unit & \multicolumn{1}{c|}{ Jumlah } \\
\hline 1. & Gula Merah Kecil & 260 & $\mathrm{Kg}$ & $\mathrm{Rp} 17.566$ & $\mathrm{Rp} 4.567 .160$ \\
\hline 2. & Gula Merah Besar & 260 & $\mathrm{Kg}$ & $\mathrm{Rp} 17.566$ & $\mathrm{Rp} 4.567 .160$ \\
\hline \multicolumn{2}{|}{ Jumlah } & $\mathbf{5 2 0}$ & & & Rp9.134.320 \\
\hline
\end{tabular}

Sumber : Diolah Penulis 
Tabel 3. Daftar Produksi Barang Jadi Periode November 2020

\begin{tabular}{|c|c|c|c|r|r|}
\hline No. & Nama Barang & Unit & Satuan & Harga/Unit & \multicolumn{1}{c|}{ Jumlah } \\
\hline 1. & Gula Merah Kecil & 260 & $\mathrm{Kg}$ & $\mathrm{Rp} 17.777$ & $\mathrm{Rp} 4.622 .020$ \\
\hline 2. & Gula Merah Besar & 260 & $\mathrm{Kg}$ & $\mathrm{Rp} 17.777$ & $\mathrm{Rp} 4.622 .020$ \\
\hline \multicolumn{2}{|c}{ Jumlah } & $\mathbf{5 2 0}$ & & & $\mathbf{R p 9 . 2 4 4 . 0 4 0}$ \\
\hline
\end{tabular}

Sumber: Diolah Penulis

Tabel 4. Daftar Produksi Barang Jadi Periode Desember 2020

\begin{tabular}{|c|c|c|c|c|c|}
\hline No. & Nama Barang & Unit & Satuan & Harga/Unit & \multicolumn{1}{c|}{ Jumlah } \\
\hline 1. & Gula Merah Kecil & 260 & $\mathrm{Kg}$ & $\mathrm{Rp} 17.942$ & $\mathrm{Rp} 4.664 .920$ \\
\hline 2. & Gula Merah Besar & 260 & $\mathrm{Kg}$ & $\mathrm{Rp} 17.942$ & $\mathrm{Rp} 4.664 .920$ \\
\hline \multicolumn{2}{|c|}{ Jumlah } & $\mathbf{5 2 0}$ & & & Rp9.329.840 \\
\hline
\end{tabular}

Sumber : Diolah Penulis

Tabel 5. Daftar Penjualan Barang Jadi Periode 01 Oktober - 31 Desember 2020

\begin{tabular}{|c|c|c|c|r|r|}
\hline No. & Nama Barang & Unit & Satuan & Harga/Unit & \multicolumn{1}{c|}{ Jumlah } \\
\hline 1. & Gula Merah Kecil & 800 & $\mathrm{Kg}$ & $\mathrm{Rp} 24.000$ & $\mathrm{Rp} 19.200 .000$ \\
\hline 2. & Gula Merah Besar & 800 & $\mathrm{Kg}$ & $\mathrm{Rp} 23.000$ & $\mathrm{Rp} 18.400 .000$ \\
\hline \multicolumn{2}{|c|}{ Jumlah } & $\mathbf{1 6 0 0}$ & & & Rp37.600.000 \\
\hline
\end{tabular}

Sumber: Diolah Penulis

Tabel 6. Daftar Persediaan Akhir Barang Jadi Periode 31 Desember 2021

\begin{tabular}{|c|l|c|c|r|rr|}
\hline No. & Nama Barang & Unit & Satuan & Harga/Unit & Jumlah & \\
\hline 1. & Gula Merah Kecil & 0 & $\mathrm{Kg}$ & $\mathrm{Rp0}$ & $\mathrm{Rp0}$ \\
\hline 2. & Gula Merah Besar & 0 & $\mathrm{Kg}$ & $\mathrm{Rp0}$ & $\mathrm{Rp0}$ \\
\hline \multicolumn{2}{c}{ Jumlah } & $\mathbf{0}$ & & & Rp0 \\
\hline
\end{tabular}

Sumber : Diolah Penulis

\section{Pembahasan}

Evaluasi Terhadap Sistem Pencatatan dan Penilaian Persediaan Barang Jadi

Berdasarkan evaluasi Setiap barang jadi yang masuk maupun yang keluar pada UMKM ini tidak dibuatkan pencatatannya sebagai bukti atau arsip perusahaan yang sesuai dengan standar akuntansi yang berlaku. Pada jenis perusahaan manufaktur terutama pada bidang produksi makanan, pencatatan persediaan menggunakan metode Masuk Pertama Keluar Pertama (MPKP) - perpetual merupakan yang sering digunakan. Metode tersebut memiliki keunggulan yang mendukung agar produk yang pertama kali diproduksi menjadi produk yang didulukan untuk dijual. Sehingga dapat mengurangi risiko produk kadaluwarsa di gudang. Pencatatannya yang dilakukan terus menerus juga membuat sistem pencatatan perpetual menjadi pilihan yang efektif untuk mempermudah pihak yang berkepentingan mengetahui saldo persediaan dalam perusahaannya.

Berdasarkan data yang diperoleh, dapat dibuat laporan laba rugi perusahaan sebagai berikut: 
Tabel 7. Laporan Laba Rugi

Usaha Gula Merah Ibu Laila

Periode 01 Oktober - 31 Desember 2020

\begin{tabular}{|lr|}
\hline PENDAPATAN & \\
Penjualan & Rp37.600.000 \\
Penjualan lain - lain & XXX \\
\cline { 2 - 2 } JUMLAH PENDAPATAN & $\mathrm{Rp} 37.600 .000$ \\
\hline BEBAN & $\mathrm{Rp} 28.388 .200$ \\
Harga Pokok Produksi & XXX \\
Beban Usaha & $\mathrm{Rp} 28.388 .200$ \\
\hline JUMLAH BEBAN & $\mathbf{R p 9 . 2 1 1 . 8 0 0}$ \\
\hline
\end{tabular}

Sumber : Diolah Penulis

Berikut adalah hasil penelitian penulis pada Usaha Gula Merah Ibu Laila mengenai pencatatan dan penilaian persediaan barang jadi yang berdasarkan standar akuntansi yang berlaku bagi jenis UMKM sesuai dengan kondisi Usaha Gula Merah Ibu Laila. Pencatatan dan penilaian persediaan yang sesuai dengan standar tentu akan sangat membantu pihak perusahaan dalam menentukan laba rugi untuk mengevaluasi kinerja perusahaan berdasarkan data yang lebih dapat dipertanggungjawabkan.

Data dan hasil penelitian dapat dijadikan sebagai sumber referensi bagi pihak yang membutuhkan untuk membuat pencatatan dan penilaian persediaan barang jadi pada jenis UMKM terutama pada Usaha Gula Merah Ibu Laila yang belum melakukan pencatatan dan penilaian persediaannya sesuai dengan standar akuntansi yang berlaku.

\section{Kesimpulan}

Berdasarkan penelitan yang telah dilakukan penulis, Usaha Gula Merah Ibu Laila melakukan perhitungan persediaan barang jadi pada perusahaannya apabila akan menghitung laba atau rugi perusahaan. Namun perusahaan Usaha Gula Merah Ibu Laila belum melakukan pencatatan dan penilaian persediaan barang jadi sesuai dengan standar akuntansi yang berlaku bagi jenis UMKM. Entitas ini hanya menghitung berdasarkan perkiraan dalam kertas buram atau buku catatan harian yang tidak diperuntukkan disimpan atau menjadi bahan evaluasi perusahaan yang dapat dipertanggungjawabkan

\section{Referensi}

Agus, R. (2019). Pengakuan dan Pengukuran Serta Penyajian Persediaan Barang Dagangan Dengan Menggunakan Metode MPKP Berdasarkan SAK EMKM Pada Apotek Firdaus Banjarmasin. Politeknik Negeri Banjarmasin.

Barchelino, R. (2016). Analisis Penerapan Psak No. 14 Terhadap Metode Pencatatan Dan Penilaian Persediaan Barang Dagangan Pada PT Surya Wenang Indah Manado. Jurnal Riset Ekonomi, Manajemen, Bisnis Dan Akuntansi, 4(1), 837-846.

Budianto, H., \& Ferriswara, D. (2017). Penerapan Metode Pencatatan dan Penilaian Persediaan Barang menurut SAK ETAP pada CV Tjipto Putra Mandiri Indonesia. Jurnal Aplikasi Administrasi, 20(2), $124-138$.

Hermanto, M., Sondakh, J. J., \& Pangerapan, S. (2019). Analisis Perlakuan Akuntansi Atas Persediaan Pada Perum Bulog Divre Sulut Dan Gorontalo. Jurnal Riset Ekonomi, Manajemen, Bisnis Dan 
Akuntansi, 7(1), 1131-1140.

Hutauruk, W. (2019). Analisis Faktor-Faktor Yang Mempengaruhi Pemilihan Metode Penilaian Persediaan Pada Perusahaan Manufaktur Subsektor Industri Makanan dan Minuman Yang terdaftar di Bursa Efek Indonesia.

Ikatan Akuntan Indonesia. (2016). Standar Akuntansi Keuangan Entitas Mikro, Kecil, dan Menengah. Dalam SAK EMKM Ikatan Akuntan Indonesia, 1-54.

Karongkong, K. R., Ilat, V., \& Tirayoh, V. Z. (2018). Penerapan Akuntansi Persediaan Barang Dagang Pada UD Muda-Mudi Tolitoli. Jurnal Riset Akuntansi, 13(02), 46-56.

Karundeng, A., Saerang, D., \& Gamaliel, H. (2017). Analisis Perlakuan Akuntansi Atas Persediaan Barang Jadi Sesuai Dengan PSAK No.14 Pada PT Fortuna Inti Alam. Jurnal Riset Akuntansi, 12(1), 20-28.

Khadijah, S. (2019). Pencatatan dan Penilaian Persediaan Barang Dagang Menggunakan SAK EMKM (Standar Akuntansi Keuangan Entitas Micro, Kecil, dan Menengah) Pada Toko Bangunan Dua Mas Rilly Pelaihari. Politeknik Negeri Banjarmasin.

Lestari, D., Subagyo, \& Limantara, A. (2019). Analisis Perhitungan Persediaan Bahan Baku Dengan Metode Fifo Dan Average (Study Kasus Pada UMKM Aam Putra Kota Kediri). Jurnal Akuntansi, 09(02), 25-47.

Lulianto, D., Anastasya, S., \& Sari, A. R. (2016). Analisis Metode Pencatatan dan Penilaian Persediaan Sesuai PSAK No.14 pada PT Toeng Makmur. Jurnal Riset Mahasiswa Akuntansi Unikama, 4(1), 110.

Mangopa, S., Tuli, H., \& Mahmud, M. (2020). Analisis Penerapan SAK EMKM Persediaan Pada Usaha Mikro \& Kecil Sektor Ritel Barang Harian. Jambura Accounting Review, 1(2), 70-83.

Mardatillah, A. (2020). Analisis Penerapan Sistem Pencatatan Dan Penilaian Persediaan Barang Dagang Oleh Karyawan Toko Tokyo Style Ditinjau Dari Perspektif Ekonomi Islam. Dalam Universitas Islam Negeri Sultan Syarif Kasim Riau. Universitas Islam Negeri Sultan Syarif Kasim Riau.

Wullur, R. A. M. L., Karamoy, H., \& Pontoh, W. (2016). Analisis Penerapan Akuntansi Persediaan Berdasarkan Psak No.14 Pada PT Gatraco Indah Manado. Jurnal Riset Akuntansi, 11(1), 1-9.

Yosefa, S. T. (2016). Penerapan Metode Pencatatan Dan Penilaian Persediaan Menurut Psak No.14 Pada PT Nippon Indosari Corpindo, Tbk. Jurnal FinAcc, 1(14), 1479-1490. 